\title{
Scanning Electron Microscopy Study of the Dorsal Surface of the Tongue in the Slow Loris (Nycticebus coucang) and Pygma Slow Loris (N.pygmaeus)
}

\author{
Estudio de Microscopía Electrónica de Barrido de la Superficie Dorsal de La Lengua \\ en Lori Perezoso (Nycticebus coucang) y Lori Perezoso Pigmeo (N.pygmaeus)
}

Zhaohui Xie \& Rui Zhang

ZHAOHUI, X. \& ZHANG, R. Scanning electron microscopy study of the dorsal surface of the tongue in the Slow Loris (Nycticebus coucang) and Pygma Slow Loris (N. pygmaeus). Int. J. Morphol., 35(2):520-524, 2017.

SUMMARY: The dorsal surface of the tongues of the Slow Loris and the Pygma Slow Loris were examined by employing scanning electron microscopy techniques. Three types of the papillae are present on their dorsal surface of the tongue: filiform, fungiform and vallate. The filiform papillae are located the apex and the body of the tongue, and we observed that each of them has a gustatory pore. The fungiform papillae, scattered singly among the filiform papillae, distribute mainly on the apex of the tongue. The vallate papillae are located along the diversing arms of the V-shaped boundary between the anterior and posterior regions of the tongue. In addition, no foliate papillae were observed. The morphological characteristics of the dorsal surface of the tongues in Slow Loris and Pygma Slow Loris are similar to each other.

KEY WORDS: Nycticebus; Lingual Papillae; Primate; SEM; Tongue.

\section{INTRODUCTION}

The Slow Loris (Nycticebus coucang) and the Pygma Slow Loris (Nycticebus pygmaeus), two distinct species of Nycticebus, one genus of Lorisidae, belong to the Strepsirrhini, an ancient group of primates. They are the only nocturnal animals among all the primates that have been found in China so far (Nekaris \& Nijman, 2007). Tropical and subtropical evergreen and semi-evergreen rainforests with continuous dense canopies and forest edges are their preferred habitats. The Slow Loris mainly lives in tropical and subtropical evergreen and semi-evergreen rainforests, and the Pygma Slow Loris lives in semi-evergreen and secondary forests (Srivastava \& Mohnot, 2001). Their main distribution area in China is tropical and subtropical rainforest in Yunnan and southern Guangxi, China. They feed on a mixed diet, with the majority of the food items consisting of fruits, vegetables, insects, honey, fresh leaves and berries.

Numerous studies on the structure of the dorsal surface of the tongue in vertebrates have been reported: in reptile (Carmignani \& Zaccone, 1975); in amphibians (Zuwaa \& Jakubowski, 2001; Zuwaa \& Jakubowski, 2007); in birds (Emura et al., 2009; Emura et al., 2008), and in mammals (Levin \& Pfeiffer, 2002; Yoshimura, 2002). Many studies have investigated the structure of the dorsal surface of the tongue in primates (Machida et al., 1967; Arvidson, 1976) and, in monkeys, Macaca fuscata and Cercropithecus aethiopus (Emura et al., 2002), Macaca irus (Iwasaki, 1992) and Macaca fuscata (Iwasaki et al., 1992a). Unfortunately, there is no report on the morphological characteristic of the lingual papillae under SEM in Slow Loris and Pygma Slow Loris. The aim of this study was to examine the dorsal surface of the lingual papillae of Slow Loris and Pygma Slow Loris, and to distinguish the differences between the tongues of them.

\section{MATERIAL AND METHOD}

Seven adult Slow Loris and 4 adult Pygma Slow Loris were rescued from wildlife traffickers by the Wildlife Rescue and Rehabilitation Center of Henan province in October 2010 in Xinxiang, Henan province, China. The average weights of them were $963.8 \mathrm{~g}$ and $391.7 \mathrm{~g}$. Adult Slow Loris and 4 adult Pygma Slow Loris that died eventually due to the lack of rescue experience and guidance were used in our study. And the other 6 were taken to Xishuangbanna Nature Reserve for releasing. There was no animal sacrificed in this study. 
For scanning electron microscopic (SEM) observation, tongue samples were fixed at $4{ }^{\circ} \mathrm{C}$ in $2.5 \%$ glutaraldehyde with phosphate buffer ( $\mathrm{pH} 7.2)$. After washing in fresh buffer, the tissues were additionally fixed for $1 \mathrm{~h}$ in $1 \%$ buffered aqueous $\mathrm{OsO}_{4}$ solution. They were dehydrated in a series of acetone concentration, starting with a $50 \%$ solution, and then dried with critical-point-dryer, coated with gold and observed at various different angles under the scanning electron microscope (SEM) FEL QUANTA 450 at 30KV.

\section{RESULTS}

The tongue of the adult slow Loris measured about $24 \mathrm{~mm}$ in length and about $18 \mathrm{~mm}$ in width, and that of the adult Pygma slow Loris was about $17 \mathrm{~mm}$ and $6 \mathrm{~mm}$, respectively. Three types of the papillae are present on the dorsal surface of the tongue of the Slow Loris and the Pygma Slow Loris: filiform, fungiform and vallate (Figs. 1,2 and 3).
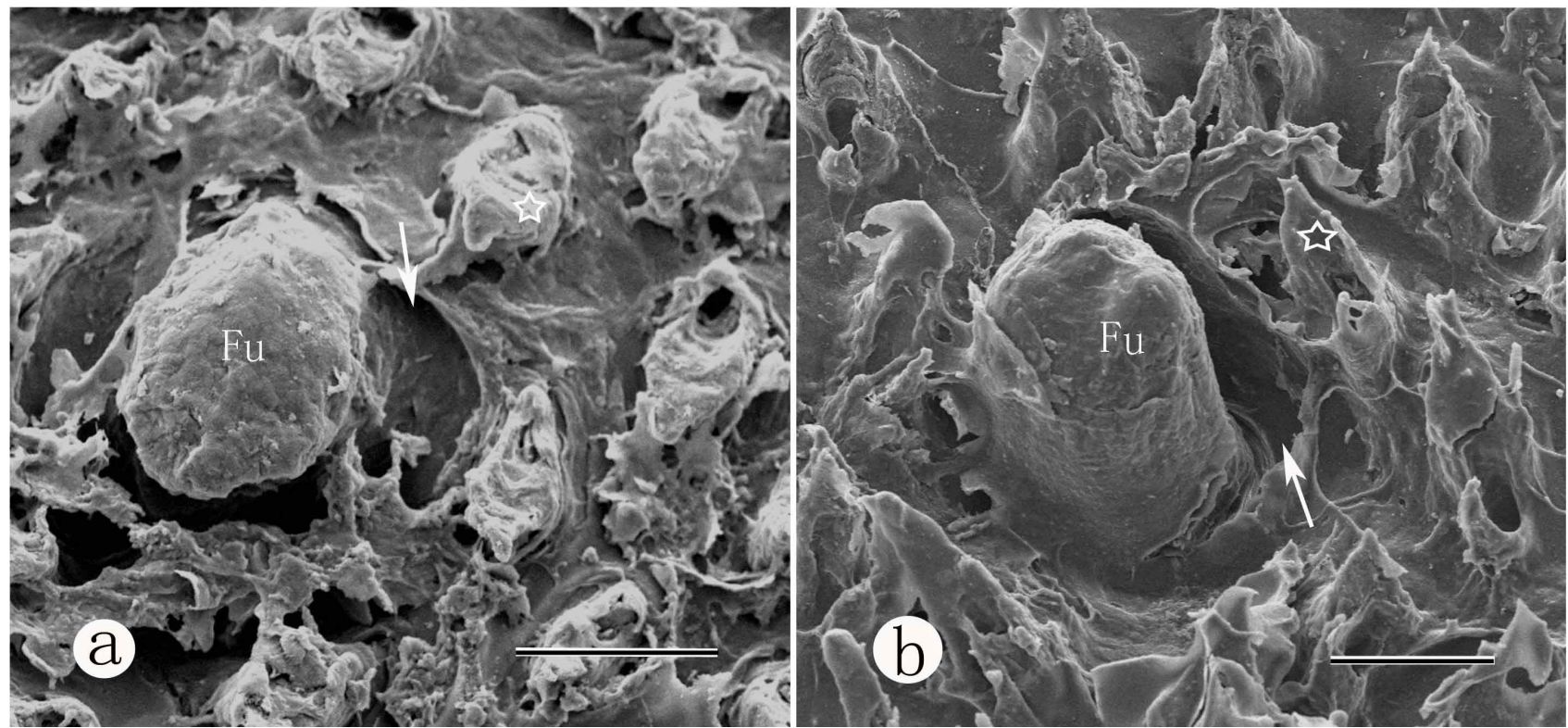

Fig. 1. A set of scanning electron micrographs of Fungiform papillae. (a)Slow Loris. (b) Pygmy Loris. Fu, fungiform papilae; Arrows, openings of the lingual glands; Star showed filiform papillae. Scale bar $=100 \mathrm{~mm}$.
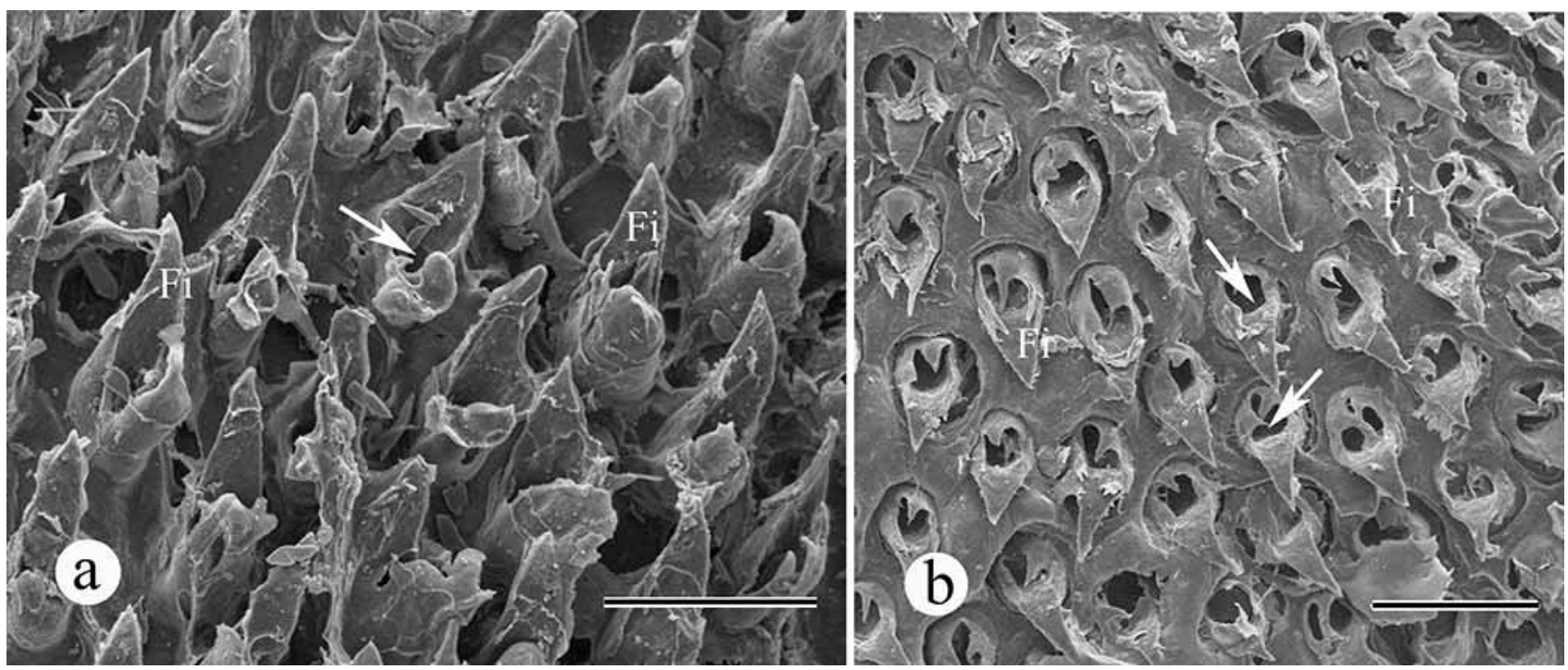

Fig. 2. A set of scanning electron micrographs of filiform papillae. (a)Slow Loris. (b) Pygmy Loris. Fi, filiform papillae; Arrows, openings of the lingual glands. Scale bar $=250 \mathrm{~mm}$. 
The filiform papillae, which are conical or branched, consisting of one main thick process and several slender accessory processes, can be found on the apex and body of the tongue, pointing principally towards the pharynx (Fig. 2a, 2b). Filiform papillae are arranged in distinct rows, decreasingly in number and length throughout the posterior third. Furthermore, the filiform papillae are abundant at the tip of the tongue. Each filiform papilla is approximately 100 $\mathrm{mm}$ in diameter in Slow Loris (Fig. 2a) and $105 \mathrm{~mm}$ in Pygma (Fig. 2b). Each filiform papilla possesses a gustatory pore which is approximately $80 \mathrm{~mm}$ in diameter. There is a circular concavity in each pore. The filiform show conical shaped in Slow loris, and the filiform papillae showed flatconical shaped in Pygma slow lorise.

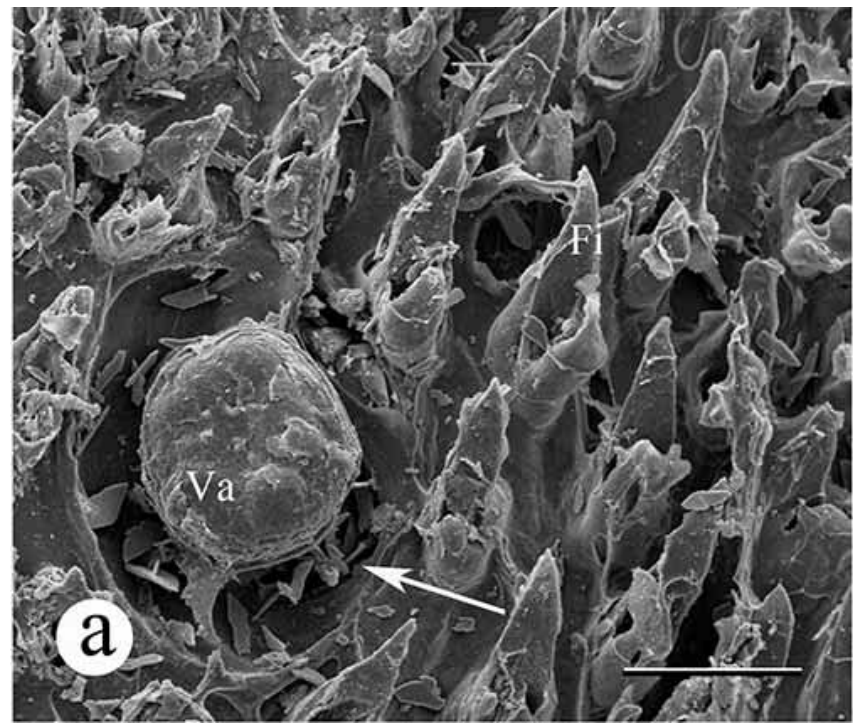

Fig. 3. A set of scanning electron micrographs of vallate papillae. papillae. Arrows, circular furrow can be seen. Scale bar $=250 \mathrm{~mm}$.

\section{DISCUSSION}

This study has demonstrated three types of papillae, filiform, fungiform and vallate, in Slow Loris and Pygma Slow Loris, employing scanning electron microscopic technique. Overall, the morphological patterns of the tongues were not different from other species in primates (Arvidson; Ferguson, 1980; Iwasaki, 1992; Iwasaki et al., 1992a; Emura et al., 2002).

Study on the Slow loris interspecific at the genetic level by Chen et al. (2004) suggested that there were significant differences between Slow Loris and Pygma Slow Loris, which showed that they were two efficient species. Additionally, our previous work has also mentioned (Xie $e t$ al., 2013).
The fungiform papillae, distributed mainly on the apex of the dorsal surface, present a round or dome in shape. And they are scattered singly among the filiform papillae. They are of larger size to the filiform ones; each fungiform papillae are approximately $126 \mathrm{~mm}$ in diameter in Slow Loris (Fig. 1a) and $153 \mathrm{~mm}$ in Pygma (Fig. 1b).

The vallate papillae, have the round or oral shape, located along the diversing arms of the $\mathrm{V}$-shaped boundary between the anterior and posterior regions of the tongue. And they are sunk into the surface of the mucous membrane and each is surrounded by a deep, circular, furrow (Fig. 3). The vallate papillae is approximately $316 \mathrm{~mm}$ in diameter in Slow loris (Fig. 3A ) and $264 \mathrm{~mm}$ in Pygma (Fig. 3B).

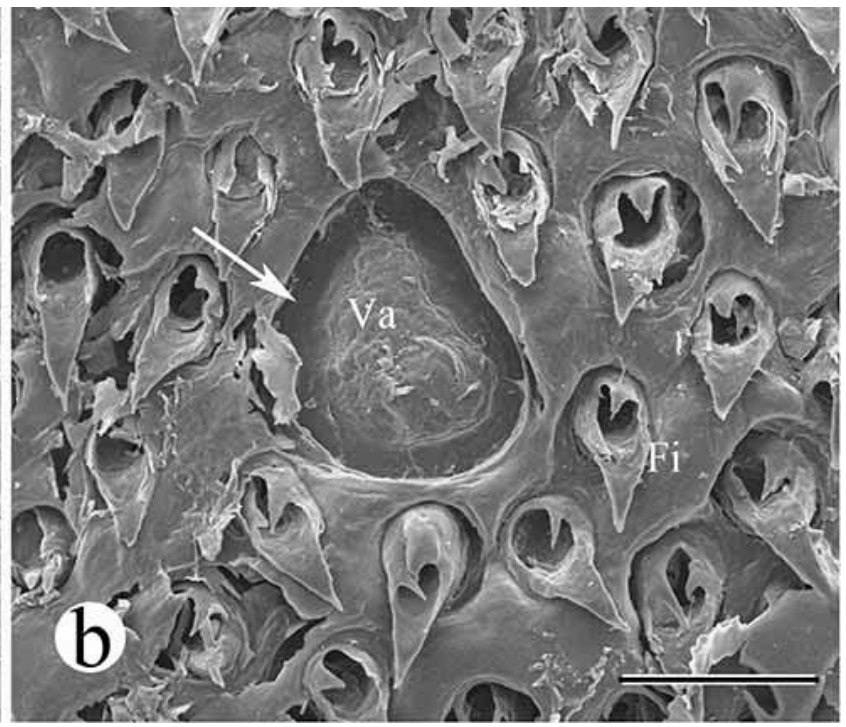

(A)Slow Loris. (B) Pygmy Loris. Va, vallate papillae. Fi, fililorm
Previous research in the dorsal surface of the tongue in mammals has emphasized the connective tissue cores and the different types of filiform papillae (Yoshimura; Emura et al., 2004). In this paper, we discussed the pattern of the filiform papillae already. And numerous filiform papillae cover the surface of the lingual dorsum, seems to be similar in the tongue of Bradypus torquatus (Benetti et al., 2009), Myocastor coypus tongue (Ünsal et al., 2003) and Macaca fuscata and Cercopithecus aethiopus tongues (Emura et al., 2002). According to Iwasaki (2002), the characteristic of the lingual papillae, especially filiform papillae, are similar within the same genus, which is consistent with our appearance of the keratinization of the epithelium in the observations in Slow Loris and Pygma Slow Loris. The 
filiform papillae, which is similar in most mammals, can sustain strong physical force (Iwasaki, 2002). It is noted that the filiform papillae are easily bent in the direction of the radix but not in the opposite direction, being probably connected the need for moving the food taken into the mouth (Iwasaki, 2002). At a high degree of magnification, we observed a gustatory pore in the central of the each filiform papillae, probably related to the types of food and the feeding habits in Slow Loris and Pygma Slow Loris. Moreover, further studies are needed to evaluate such assumption.

Regarding the fungiform papillae, several microridges can be identified on the dorsal surface of the fungiform papillae. The pattern and the shape have been established in the literature, referring to the reports in primates (Kobayashi et al., 2004). The fungiform papillae in Slow Loris and Pygma Slow Loris, furnished with taste buds, perform gustatory functions in monkey (Arvidson).

The distribution of vallate papillae in Slow Loris and Pygma Slow Loris, with three papillae arranged in an inverted pattern of $\mathrm{V}$-shape, is also found in primates (Kubota \& Hayama, 1964; Emura et al., 2002). The shape of the posterior central papillae differs from the lateral ones as is mentioned in Marmosets (Kubota \& Hayama) and Saimiri (Iwasaki et al., 1988; Matsukawa \& Okada, 1994). In addition, the number of the vallate papillae is various, such as Japanese monkey (Iwasaki et al., 1992b). At a high degree of magnification, circular furrows are evident. The circular furrows, surrounding the vallate papillae, separates the vallate papillae from the mucosa covered with filiform papilla.

According to Kubota \& Hayama, the tongues of pigmy and common marmosets have the foliate papillae with a few clefts, while, Matsukawa \& Okada stated that no foliate papillae were observed in the squirrel monkey and marmoset. And in our study, we could not find any foliate papillae in Slow Loris and Pygma Slow Loris.

The morphological characteristics of the tongues in Slow Loris and Pygma Slow Loris are similar to each other. However, the feature of the filiform papillae is different. The morphological variations of the tongues, especially the filiform papillae in Slow Loris and Pygma Slow Loris may be the reason of being dependent on the evolutional taxonomy of primate species.

\section{ACKNOWLEDGEMENTS}

We would like to thank Dajun DENG from Henan Wild Animal Protection Center and Jianye HU from Henan University of Urban Construction for their great help in specimen collection.

ZHAOHUI, X. \& ZHANG, R. Estudio de microscopía electrónica de barrido de la superficie dorsal de la lengua en lori perezoso (Nycticebus coucang) y lori perezoso pigmeo (N. pygmaeus). Int. J. Morphol., 35(2):520-524, 2017.

RESUMEN: La superficie dorsal de la lengua en lori perezoso y lori perezoso pigmeo fue examinada utilizando técnicas de microscopía electrónica de barrido. Se observaron tres tipos de papilas presentes en la superficie dorsal de la lengua: filiforme, fungiforme y valada. Las papilas filiformes se localizaban en el ápice y en el cuerpo de la lengua, y observamos que cada una tenía un poro gustativo. Las papilas fungiformes están distribuidas individualmente entre las papilas filiformes, principalmente en el ápice de la lengua. Entre las regiones anterior y posterior de la lengua se observan las papilas valadas a lo largo de las extensiones del margen en forma de ' $V$ '. Además, no se observaron papilas foliadas. Las características morfológicas de la superficie dorsal de las lenguas en lori perezoso y lori perezoso pigmeo son similares entre sí.

PALABRAS CLAVE: Nycticebus; Papilas linguales; Primate; SEM; Lengua.

\section{REFERENCES}

Arvidson, K. Scanning electron microscopy of fungiform papillae on the tongue of man and monkey. Acta. Otalaryngol., 81(5-6):496-502, 1976.

Benetti, E. J.; Pícoli, L. C.; Guimarães, J. P.; Motoyama, A. A.; Miglino, M. A. \& Watanabe, L. S. Characteristics of filiform, fungiform and vallate papillae and surface of interface epithelium-connective tissue of the maned sloth tongue mucosa (Bradypus torquatus, Iliger, 1811): Light and Scanning Electron Microscopy Study. Anat. Histol. Embryol., $38(1): 42-8,2009$

Carmignani, M. P. \& Zaccone, G. Histochemical distribution of acid mucopolysaccharides in the tongue of reptiles. I. Chelonia (Pseudemys scripta Clark). Ann. Histochim., 20(1):77-88, 1975.

Chen, J. H.; Crow, P.; Narushima, E.; Zhang, H. W. \& Zhang, Y. P. Molecular phylogeny of Slow Lorises (Nycticebus) revealed by D-loop sequences and complete cytochrome b gene sequences of mitochondrial DNA. Zool. Res., 25(4):292-7, 2004.

Emura, S.; Hayakawa, D.; Chen, H. \& Shoumura, S. Morphology of the dorsal lingual papillae in the Japanese macaque and Savanna monkey. Anat.Histol. Embryol., 31(5):313-6, 2002. 
Emura, S.; Hayakawa, D.; Chen, H. \& Shoumura, S. Morphology of the lingual papillae in the tiger. Okajimas Folia Anat. Jap., 81(2-3):39-43, 2004.

Emura, S.; Okumura, T. \& Chen, H. Scanning electron microscopic study of the tongue in the peregrine falcon and common kestrel. Okajimas Folia Anat. Jpn., 85(1):11-5, 2008.

Emura, S.; Okumura, T \& Chen, H. Scanning electron microscopic study of the tongue in the Oriental scops owl (Otus scops). Okajimas Folia Anat. Jpn., 86(1):1-6, 2009.

Ferguson, M. W. J. Living new world monkeys (Platyrrhini). With an introduction to primates. J. Anat., 130(Pt. 2):442-3, 1980.

Iwasaki, S. Fine structure of the dorsal lingual epithelium of the crab-eating monkey, Macaca irus. Ann. Anat., 174(6):523-9, 1992.

Iwasaki, S.; Yoshizawa, H, \& Suzuki K. Fine structure of the dorsal lingual epithelium of the Japanese monkey, Macaca fuscata fuscata. Acta. Anat. (Basel), 144(3):267-77, 1992a.

Iwasaki, S.; Asami, T.; Asami, Y. \& Kobayashi, K. Fine structure of the dorsal epithelium of the tongue of the Japanese terrapin, Clemmys japonica (Cheloia, Emydinae). Arch. Histol. Cytol., 55(3):295-305, 1992b.

Iwasaki, S.; Miyata, K. \& Kobayashi, K. Scanning-electron-microscopic study of the dorsal lingual surface of the squirrel monkey. Acta. Anat. (Basel), 132(3):225-9, 1988.

Iwasaki, S. Evolution of the structure and function of the vertebrate tongue. J. Anat., 201(1):1-13, 2002.

Kobayashi, K.; Kumakura, M.; Yoshimura, K.; Takahashi, M.; Zeng, J. H.; Kageyama, I.; Kobayashi, K. \& Hama, N. Comparative morphological studies on the stereo structure of the lingual papillae of selected primates using scanning electron microscopy. Ann. Anat., 186(5-6):525-30, 2004.

Kubota, K. \& Hayama, S. Comparative anatomical and neurohistological observations on the tongues of pigmy and common marmosets. Anat. Rec., 150(4):473-85, 1964.

Levin, M. J. \& Pfeiffer, C. J. Gross and microscopic observations on the lingual structure of the Florida Manatee Trichechus manatus latirostris. Anat. Histol. Embryol., 31(5):278-85, 2002.

Machida, H.; Perkins, E. \& Giacometti, L. The anatomical and histochemical properties of the tongue of primates. Folia Primatol., 5:264-79, 1967.

Matsukawa, N. \& Okada, S. Microvasculature of the lingual papillae in primates and insectivores--fungiform, vallate and foliate papillae. Okajimas Folia Anat. Jpn., 71(4):259-77, 1994.

Nekaris, K. A. \& Nijman, V. CITES proposal highlights rarity of Asian nocturnal primates (Lorisidae: Nycticebus). Folia Primatol. (Basel), 78(4):211-4, 2007

Srivastava, A. \& Mohnot, S. M. Distribution, conservation status and priorities for primates in Northeast India. Envis. Bull., 1(1):102-8, 2001.

Ünsal, S.; Aktümsek, A.; Celik, I. \& Sur, E. The number and distribution of fungiform papillae and taste buds in the tongue of young and adult Akkaraman sheep. Revue. Méd. Vét., 154(11):709-14, 2003.

Xie, Z. H.; Hu, J. Y.; Zhou, M. Y. \& Deng, D. J. Characteristics of the limb in slow loris and pygmy loris. Chin. J. Anat., 36(3):405-7, 2013.

Yoshimura, K.; Shindoh, J. \& Kobayashi, K. Scanning electron microscopy study of the tongue and lingual papillae of the California sea lion (Zalophus californianus californianus). Anat. Rec., 267(2):146-53, 2002.

Zuwaa, K. \& Jakubowski, M. Morphological differentiation of taste organs in the ontogeny of Salamandra salamandra. Anat. Embryol., 204(5):41320, 2001.

Zuwaa, K. \& Jakubowski, M. Structural diversification of the gustatory organs during metamorphosis in the alpine newt Triturus alpestris. J. Anat., 211(3):371-5, 2007.

\author{
Corresponding author: \\ A/Prof. Zhaohui Xie \\ School of Life Science and Engineering \\ Henan University of Urban Construction \\ Pingdingshan Henan \\ CHINA
}

Email: xiezhaohui@hncj.edu.cn

Received: 03-01-2017

Accepted: 09-03-2017 